\title{
JUSTYNA OlęDZKa
}

UNIWERSYTET W BIAEYMSTOKU

E-MAIL:WIJ@GO2.PL

\section{ZJAWISKO NOWEGO NACJONALIZMU NA OBSZARZE AZJI CENTRALNEJ}

\section{Nowy nacjonalizm jako kategoria ideologii politycznej w reżimach niedemokratycznych Azji Centralnej}

Następstwem rozpadu Związku Radzieckiego były nie tylko głębokie zmiany politycznej mapy regionu, ale również próżnia ideologiczna, stanowiąca ogromne wyzwanie dla elit władzy nowo powstałych państw Azji Centralnej. W poniższej analizie przyjęto koncepcję tak zwanej perspektywy krótkiego trwania, według której ideologia nacjonalistyczna była zastępcza wobec komunizmu ${ }^{1}$. Interesujące są również spostrzeżenia O. Roya i S. Hunter, określające nacjonalizm w regionie Azji Centralnej jako zjawisko stosunkowo nowe, niesygnalizujące dynamiki przed okresem radzieckim. Kluczowymi graczami bowiem były wówczas wielkie imperia, stale rozszerzające obszar podboju oraz liczne plemiona, nie zawsze przypisane do określonego terytorium - wiele z nich stanowiły ludy koczownicze.

Koncepcja administracyjna regionu, wprowadzająca w latach trzydziestych XX wieku radziecki podział na republiki związkowe, po rozpadzie ZSRR automatycznie stała się mapą polityczną Azji Centralnej. To wtedy pojawił się nacjonalizm nowego typu, w latach dziewięćdziesiątych stosunkowo prymitywne narzędzie budowy wspólnoty obywatelsko-narodowej, pozbawionej więzi innego typu (politycznej, religijnej). Deficyt argumentów legitymizacyjnych z zakresu gospodarczego i napięta sytuacja etnopolityczna na całym obszarze poradzieckim wymusiły działania na rzecz sformułowania najważniejszych i najefektywniejszych konstruktów scalających społeczeństwa, które po zdobyciu niepodległości ulegały stopniowej

$1 \quad$ Według koncepcji F. Braudela. 
erozji tożsamościowej. Procesy narodotwórcze projektować miały pragmatyczną strategię, użyteczną w bieżącej polityce wewnętrznej i zagranicznej poszczególnych - do 1991 roku w większości wielonarodowych - państw. Składowe regionu powstałe po rozpadzie Związku Radzieckiego: Kazachstan, Kirgistan, Turkmenistan, Uzbekistan i Tadżykistan, stanęły przed wyzwaniem instytucjonalizacji idei nacjonalistycznej w ramach struktur silnie zrusyfikowanych gospodarczo i kulturowo.

Pojemność modeli narodowych państw centralnoazjatyckich musiała być na tyle obszerna, by objąć również rosyjską diasporę, posiadającą wysokie aspiracje ekonomiczne i polityczne. Utrzymywany celowo przez władze komunistyczne stan napięć etnopolitycznych stanowił główne źródło problemów regionalnych reżimów politycznych u schyłku XX wieku. Niezależnie od tego, czy aktywność narodowościową uznamy za jedną z przyczyn rozpadu ZSRR, czy za jego konsekwencję, najbardziej intensywne skutki napięć etnopolitycznych doprowadziły w perspektywie krótkookresowej do wybuchu konfliktów zbrojnych, natomiast długofalowym efektem była promocja nacjonalizmu narodów tytularnych państw poradzieckich Azji Centralnej.

Zjawisko odradzania partii nacjonalistycznych, początkowo noszących cechy efemeryd sceny politycznej, znalazło zastosowanie w populistycznej retoryce przywódców państwowych, poszukujących nowych strategii legitymizacyjnych. Długotrwałe skutki aktywizacji nowego nacjonalizmu zaobserwować można w licznych sferach życia społeczno-politycznego i gospodarczego. W ramach systemu politycznego narzędzia etnopolityczne umożliwiły zachowanie państw wieloetnicznych w postaci unitarnej. Znacząca modyfikacja nastąpiła w strukturach elit politycznych, stopniowo poddawanych etnocentrycznej moderacji. Wyraźnej korekcie ulegały systemy partyjne, a w programach partii politycznych ważną cześć zajmowały hasła działań na rzecz budowy państw mononarodowych i monokulturowych. Istotnym elementem kształtowania etnicznego oblicza państw stała się kwestia nadawania i odbierania obywatelstwa, ewentualnie możliwości zachowania podwójnego obywatelstwa.

Przywódcy państw Azji Centralnej podjęli próby wykorzystania potencjału nacjonalizmu $\mathrm{w}$ procesach budowania formuł legitymizujących nowe państwowości i ich instytucjonalne przywództwo. Instrumentalizacja nowego nacjonalizmu nie doprowadziła do spontanicznego wygenerowania wspólnot narodowo-obywatelskich, ale zrutynizowała te działania, opierając je przede wszystkim na problemie zarządzania bilingwizmem i rewitalizację kulturową oraz zmiany politycznej pozycji diaspory rosyj- 
skiej i nacjonalizm gospodarczy. Próby rozerwania istniejących na obszarze poradzieckim więzi uzależnienia gospodarczego, towarzyszyły kontestacji bądź hamowaniu rozwoju projektów reintegracyjnych w obszarze gospodarki, obronności i polityki. Równolegle, w systemach politycznych, rozpoczęto dystrybucję mitów narodotwórczych i tworzenie nowej polityki historycznej. Wobec deficytu mitów narodotwórczych zaczerpniętych z historii narodów, nierzadko fabrykowano je. Wzmożono również działania propagujące etnonacjonalizm konstruowany przez identyfikację negatywną, opartą zwłaszcza na działaniach różnicujących narody tytularne od diaspory rosyjskiej².

\section{Diaspora rosyjska w poradzieckich państwach Azji Centralnej}

Państwa regionu jako spuściznę po imperium radzieckim odziedziczyły nie tylko skomplikowaną strukturę etniczną, ale także poradziecką interpretację relacji między instytucjami państwa i obywatelami heterogenicznego etnicznie społeczeństwa. W ramach komunistycznych działań na rzecz stworzenia transkulturowego obszaru cywilizacji radzieckiej, obsługiwanego przez język rosyjski, aktywnie promowano obecność Rosjan etnicznych w regionie Azji Centralnej. Z tego względu obecność rosyjskiej diaspory w państwach poradzieckich od 1991 roku jest kwestią polityczną, wzbudzającą liczne kontrowersje, ale to również problem cywilizacyjny [Всесоюзная... 2016]. Analiza tego zagadnienia wskazuje, że liczebność mniejszości rosyjskiej została znacząco zredukowana. W ostatniej dekadzie XX wieku z Turkmenistanu wyjechała znaczna część Rosjan etnicznych, dziś szacuje się że 91\% ludności stanowią Turkmeni, Rosjanie stanowią około 3,5\% (około 180 tys.), [Всесоюзная... 2016]. Kazachstan nadal jest państwem wieloetnicznym, Rosjanie stanowią około $21 \%$ populacji. Należy jednak pamiętać, że państwo to powstało z republiki radzieckiej, w której naród tytularny stanowił mniejszość. W Tadżykistanie liczebność diaspory rosyjskiej jest zaskakująco mała i stanowi około 0,5\% ogółu ludności, w Uzbekistanie stanowi około 0,85-3\% populacji [Тульский 2005].

Państwa powstałe po upadku ZSRR podjęły również różne w swej skali i intensywności działania polityczne wobec tej mniejszości narodowej. Dodatkowo Rosjanie etniczni pozostali w państwach Azji Centralnej ulegali przez dziesięciolecia procesom transkulturowym, utrudniającym im za-

Por. etniczność separacyjna i etniczność nierównościowa [Bokszański 2006: 89-93]. 
chowanie integralności kulturowej. Wskutek oddziaływania politycznych i społecznych determinantów, katalog narzędzi pozycjonowania diaspory rosyjskiej w systemach politycznych państw poradzieckich, został zredukowany przede wszystkim do kwestii etnojęzykowych. Poszczególne reżimy w zróżnicowany sposób reagowały na zmianę pozycji diaspory rosyjskiej $\mathrm{w}$ regionie. Innym ważnym czynnikiem, warunkującym procesy etnopolityczne była alokacja w regionie grup migracji zarobkowej (Uzbecy, Tadżycy w Rosji). Turkmenistan zminimalizował rolę rosyjskojęzycznej sfery polityczno-kulturowej, utrzymał jednak szereg zależności gospodarczych. Zamykano rosyjskojęzyczne instytucje naukowe oraz biblioteki, utrudniano dostęp do mediów rosyjskojęzycznych (również przez blokowanie rosyjskojęzycznych stron internetowych i uniemożliwianie kolportażu rosyjskojęzycznej prasy). Kirgistan, Uzbekistan i Tadżykistan uległy procesowi kreolizacji, wskutek którego powstała hybrydalna kultura syntezująca elementy kultury dominującej (kolonizatora) oraz naśladującej (rodzimej). Supremacja kultury dominującej spowodowała, że partycypacja w niej stała się dla autochtonów prestiżowa i nobilitująca, była i jest jednym z narzędzi pozycjonowania społecznego i politycznego. Proces ten poprzedzał szereg działań władzy radzieckiej, mających na celu fizyczną i kulturową eksterminację elit intelektualnych narodów tytularnych republik imperium.

Stosunki państw Azji Centralnej z Federacją Rosyjską zmieniały swój kształt na przestrzeni ostatniego ćwierćwiecza. Zmianom środowiska międzynarodowego nie towarzyszyły równie dynamiczne przekształcenia wewnątrz poszczególnych systemów społeczno-politycznych. Uzbekistan balansował między dążeniami do derusyfikacji (w latach dziewięćdziesiątych) i promocją partnerstwa strategicznego z Rosją - w wyniku której od 2010 roku skutecznie zatrzymano procesy derusyfikacji. Społeczeństwo uzbeckie uznać należy za rosyjskojęzyczne, silnie zrusyfikowane kulturowo i obsługiwane przez media rosyjskie. Polityczne działania Tadżykistanu wyraźnie promują znaczenie współpracy z Rosją w obszarze gospodarczym (aktywność rosyjskiego kapitału) i militarnym, ale za istotne uznać należy dopuszczenie możliwości posiadania podwójnego obywatelstwa tadżyckorosyjskiego. Silnie prorosyjskie nastawienie mają zarówno elity, jak i społeczeństwo kirgiskie, a język rosyjski jest podstawowym dla komunikacji oficjalnej i interpersonalnej. Choć Rosjanie stanowią niezbyt liczną, około 12\% diasporę, wpływowe i popularne media są rosyjskojęzyczne bądź rosyjskie. Kazachstan w polityce zagranicznej przyjął strategię wielowektorowości, ale równolegle, w przekazie publicznym Federacja Rosyjska ukazywana jest jako sojusznik strategiczny, a liczebność rosyjskiej diaspory i pozycja 
języka rosyjskiego wpływają na rosyjskojęzyczność systemu medialnego. Wyjątkiem na tle regionu jest Turkmenistan. Około 2000 roku rozpoczęto tam rugowanie języka rosyjskiego z uczelni wyższych oraz konsekwentną turkmenizację polityki publicznej.

\section{Trajektoria procesów etnopolitycznych na obszarze Azji Centralnej}

Przez 25 lat nacjonalizm w państwach Azji Centralnej przeszedł transformację. W pierwszych latach po uzyskaniu niepodległości ruchy nacjonalistyczne wyraźnie przybrały na sile, miały reprezentację polityczną i koordynowały szereg (nierzadko spontanicznych) działań etnonacjonalistycznych w obszarze kultury i edukacji. Mobilizacja etniczna znalazła swoje przełożenie w mobilizacji politycznej, początkowo dynamizującej procesy demokratyzacji, a następnie hamującej rozwój systemów partyjnych oraz stymulującej autorytaryzację reżimów. W miarę stabilizacji autorytaryzmów wykorzystywano narrację nacjonalistyczną, retradycjonalizację oraz rewitalizację islamu w bardziej nowoczesnej formie.

Po rozpadzie ZSRR inicjatywy suwerenizacyjne ożywiły procesy etniczne, religijne i narodotwórcze. Podstawową strategią legitymizacyjną reżimów azjatyckich stało się połączenie koncepcji tak zwanej nowej etniczności ze strategiczną desowietyzacją, a następnie derusyfikacją ${ }^{3}$. Wzbogacał identyfikację narodowościową islam, nieodłączna część życia społecznego i politycznego wszystkich państw regionu. Procesy transkulturowe w przestrzeni poradzieckiej były inspirowane również przez aktywność w regionie innych poza Federacją Rosyjską państw: Chin, Turcji, USA, czy Iranu.

Następny fragment instytucjonalizacji nowych nacjonalizmów, przypadł na lata dwutysięczne i był jednym z elementów wpływających na stopień autorytaryzacji reżimów politycznych. Spontaniczność oddolnych ruchów nacjonalistycznych została zahamowana przez antydemokratyczne działania władzy politycznej, a polityka następstwa etnicznego preferująca obsadę stanowisk politycznych według klucza narodowościowego wyczerpała swój potencjał. Z początkiem XXI wieku w większości państw regionu nastąpiła zmiana w obrębie polityk wewnętrznych, skutkująca zahamowaniem procesów intensywnej etnizacji. Na przykład, w Kirgistanie wobec masowej emigracji rosyjskich elit i dużej liczebności kirgiskiej diaspory w Rosji, prowadzono wyraźnie prorosyjską politykę, demonstrując kirgizację jedynie

Tylko w latach dziewięćdziesiątych w Turkmenistanie i Tadżykistanie zamknięto ponad 2/3 szkół rosyjskojęzycznych, a w Kazachstanie i Uzbekistanie - połowę. 
w obszarze nowej polityki historycznej, pełniącej funkcje wyraźnej kompensacji kirgiskiego kompleksu niższości wobec diaspory rosyjskiej [Имакеев 2001]. Wówczas Moskwa zaktywizowała projekty reintegracji przestrzeni poradzieckiej, a dzięki zmianie koniunktury na światowych rynkach surowców energetycznych i poprawie sytuacji gospodarczej w Rosji, jej rynek pracy otworzył się gastarbeiterów $\mathrm{z}$ regionu.

Kolejny etap w rozwoju procesów etnopolitycznych rozpoczął 2014 rok i wydarzenia mające miejsce poza państwami azjatyckimi - aneksja Krymu i destabilizacja wschodniej Ukrainy. Państwa regionu Azji Centralnej, zarówno w sferze politycznej, jak i społecznej, rozpoczęły działania umożliwiające zachowanie suwerenności lub neutralności w polityce zagranicznej oraz stabilności w polityce wewnętrznej. Firmowane przez Rosję projekty integracyjne zostały zahamowane $\mathrm{z}$ powodu niechęci do współpracy sygnalizowanej przez partnerów. Obawy przed zastosowaniem instrumentalizacji diaspory rosyjskiej w polityce międzynarodowej oraz zagrożenie wzrostem natężenia postaw roszczeniowych prezentowanych przez Rosjan etnicznych, spowodowały powrót do oficjalnej retoryki państwowej haseł nacjonalistycznych.

\section{Zakończenie}

Podbój przez carskie imperium, a następnie istnienie ZSRR, pozostawiło na obszarze Azji Centralnej spuściznę w postaci kultury hybrydalnej, łączącej elementy autochtoniczne z radzieckimi i rosyjskimi. Procesy transkulturowości aktywne były więc już na długo przez transformacją systemową państw regionu. Dodatkowo, polityka etniczna komunistów stymulowała fragmentaryzację etniczną określaną jako „szachownica narodów”, współcześnie ujawniającą się w postaci istnienia licznych diaspor i enklaw narodowościowych, wyposażaniem narodowości i grup etnicznych w różny status polityczny, kulturowy i ekonomiczny.

Intensyfikacja procesów transkulturowych w państwach Azji Centralnej determinowana jest przez szereg czynników, z których za najistotniejsze uznać można:

- działania na rzecz realizacji projektów konsolidacji Rosjan etnicznych, zamieszkujących przestrzeń poradziecką;

- wdrożenie instrumentów integracji środowisk imigracji zarobkowej obecnych w Federacji Rosyjskiej; 
- instytucjonalizację subetnosu azjatyckich Rosjan, zbliżenie tej grupy do nierosyjskiego środowiska etnicznego lub wzmocnienie kontaktów $\mathrm{z}$ ojczyzną;

- zmianę poziomu intensywności nastrojów antyrosyjskich oraz przyjmowanie określonych rozwiązań państwowych w ramach derusyfikacji językowej;

- przemiany pokoleniowe, redukujące sieci powiązań i kontaktów osobistych i zawodowych w regionie.

Dynamiczne procesy transkulturowe stanowią istotny element katalogu narzędzi soft power, znajdujących się w dyspozycji władz państw regionu Azji Centralnej i Federacji Rosyjskiej. Zmienność procesu transkulturowości jest wielkim atutem w kontekście geopolityki obszaru, pozwala bowiem stymulować określone zachowania intensyfikujące związki polityczne, społeczne, kulturowe i gospodarcze. Analiza trajektorii dynamiki procesów transkulturowych w państwach centralnoazjatyckich, dowodzi, że można odwrócić określone tendencje i popularyzować oczekiwane w geopolitycznej grze zachowania. Jeśli projekt konstrukcji „,rosyjskiego świata” posługującego się wspólnym kodem kulturowym, obsługiwanego przez jeden język się powiedzie, doświadczenia $z$ lat dziewięćdziesiątych, budowy nowoczesnej tożsamości narodowej w Kazachstanie, Kirgistanie, Tadżykistanie czy Uzbekistanie zostaną zmarginalizowane. Hasło konstruowania nowego nacjonalizmu pozostanie wówczas wyłącznie w obszarze historycznego doświadczenia nowo powstałych państw poradzieckich. Zadać można pytanie, czy na obszarze tym funkcjonuje „człowiek poradziecki” jako reprezentant nowej jakości wśród grup narodowych i etnicznych? Jakie znaczenie dla procesów transkulturowych ma istnienie w Rosji potężnej grupy imigrantów zarobkowych, utrzymujących ścisłe zależności ekonomiczne z rodzinami, zamieszkującymi państwa regionu. I na ile intensywnie czynniki rosyjskiej kultury kształtują tożsamość grup imigranckich, zamieszkujących przedmieścia rosyjskich metropolii?

Praca powstała w wyniku realizacji projektu badawczego nr UMO-2014/12/S/HS5/ 00370 finansowanego ze środków Narodowego Centrum Nauki. 


\section{Bibliografia}

Bokszański Z. (2006), Tożsamości zbiorowe, Warszawa.

Brubaker R. (1998), Nacjonalizm inaczej. Struktura narodowa i kwestie narodowe w nowej Europie, Warszawa - Kraków.

Budyta-Budzyńska M. (2010), Socjologia narodu i konfliktów etnicznych, Warszawa.

Colas A. (2008), Imperium, Warszawa.

Domańska M., (2013), Uwarunkowania procesów integracyjnych i dezintegracyjnych na obszarze poradzieckim, Warszawa.

Fenton S. (2007), Etniczność, Warszawa.

Gajda J. (2014), Azja Centralna - separatyzm czy integracja z Rosją?, „Biuletyn OPINIE FAE”, $\mathrm{nr}$ 12, http://fae.pl/biuletynopiniefaeseparatyzmywazjicentralnej.pdf, [15.11.2015].

Gawrycki M. F., Szeptycki A. (2011), Podporządkowanie - niedorozwój - wyobcowanie. Postkolonializm a stosunki międzynarodowe, Warszawa.

Hunter S. T. (1996), Central Asia since Independence, Westport.

Имакеев М. (2001), Русских в Киргизии остается все меньше, „Демосцоп Вееклы”, nr 37-388. - 21 октября, http://www.demoscope.ru/weekly/037/evro09. php, [15.11.2015].

Ларюэль М. (2013), Внешняя политика и идентичность в Центральной Азии, „Pro et Contra", 1-4.

Кирчанов М. (2010), Политические и интеллектуальные мифологемы современного туркменского национализма. Региональная политика, „Журнал Центральная Азия и Кавказ", нр 1/13.

Николаева Л.Ю. (2015), Роль русского населения Таджикистана втрансбормирующемся таджикском обществе, „Сравнительная политика”, нр 2(19).

Roy O. (1996), Globalized Islam: The Search for a New Ummah, New York.

Smith A. D. (2007), Nacjonalizm, Warszawa.

Сулакшин С.С., ,Багдасарян В.Э., Вилисов М.В., Зачесова Ю.А., Пак Н.К., Середкина О.А., Чирва А.Н. (2006), Национальная идентичность России и демограбический кризис, Москва.

Szeptycki A. (2011), Brzemię Kremla, „Nowa Europa Wschodnia”, nr 3-4.

Тульский М. (2005), Итоги переписи населения Таджикистана 2000 года: национальный, возрастной, половой, семейный и образовательный составы, „Демосцоп Вееклы”, nr 191-192. -21 февраля - 6 марта 2005, http://www.demoscope.ru/ weekly/2005/0191/analit05.php, [15.11.2015].

Wierzbicki A. (2008), Etnopolityka w Azji Centralnej. Między wspólnotą etniczną a obywatelska, Warszawa.

Wierzbicki A. (2014), Etniczność i narody w Europie i Azji Centralnej, Warszawa.

Włodkowska-Bagan A. (2013), Rywalizacja mocarstw na obszarze poradzieckim, Warszawa. 
Всесоюзная перепись населения 1989 года. Национальный состав населения по республикам СССР (2016), „Демосцоп Вееклы”, nr 685-686, 9-22 мая, http://demoscope. $\mathrm{ru} /$ weekly/ssp/sng_nac_89.php?reg=12, [15.11.2015].

\section{SUMMARY}

\section{The phenomenon new nationalism in the area of Central Asia}

In the late twentieth and early twenty-first century there was a political mobilization of states built on the model of nationalistic. This trend is very clear especially in the area of Central and Eastern Europe and in Central Asia. Any attempt a new organization of the semantic concepts of statehood, citizenship, nationality, country, nationalism, ethnos, ethnic minority, diaspora, migration, etc. Showed all the imperfections and archaic conceptual apparatus used in the social sciences. Polemics calls, for example, the issue of categorization: whether Russians outside the Russian Federation should be considered diaspora, even though formally they left their country of residence, or the Russians in the former Soviet states are a classic example of a national minority and that instead the term the Russians would use the term Russian-speaking minority? Management diaspora, national and ethnic minorities, peeled by the state ethnic policy ideas have consequences in the regional and global scale, especially in the area of national and international security, economic, social and demographic and even civilizational and cultural.

KEYWORDS: new nationalism, post-Soviet region, Central Asia, the nation-state 